\title{
THE FACETS AND ECONOMIC BENEFITS OF THE INFORMATION COMMUNICATIONS TECHNOLOGY AND INNOVATIONS USED BY COMMERCIAL BANKS IN KENYA
}

\author{
Peterson Obara Magutu, Nixon Onchara Muganda \\ University of Nairobi, Nairobi, Kenya \\ magutumop@yahoo.com, nixon.muganda@gmail.com \\ Gladys Monchari Ondimu \\ Jomo Kenyatta University of Agriculture and Technology, Nairobi, Kenya \\ gladysondimu@yahoo.com
}

\begin{abstract}
The recent developments in the Information Communication Technology (ICT) have been received with great interest in research and practice by the banking community the world over. There began to appear theoretical arguments regarding the role of information technology (IT) in creating the value chain at firms and this opened up new lines of inquiry. This paper was a survey on the business value of information communication technologies in the financial departments of commercial banks in Kenya. In recognizing the significance of ICT in economic stability and growth of a country, it should not be lost on the consumers of the technologies that risks abound in every opportunity. It has also been noted that the pace of legislating the sector much of the time is overtaken by technological advancements that are directly linked to the banking sector. The research findings and recommendations are therefore expected to assist in building into the ICT and business value at departmental level, as a body of knowledge. Data was collected from a population that comprised of forty-four commercial banks incorporated and, or licensed to operate in Kenya by 2007. It was found that the two commonly used technological tools in cash management in the finance department are the financial software and e-banking. Also, the five key economic benefits of the information communications technology and innovations that have accrued to the commercial banks in Kenya at their finance departments include: ICT use has ensured proper management of account balances at value dates; ICT has helped in the monitoring and optimization of the sales-cash circuit; ICT has led to system responsiveness to changing user needs; and ICT has helped in the coverage of exchange-rate risk.
\end{abstract}

Key words: facets, benefits, information communications technology, commercial banks and Kenya.

\section{Introduction}

Banking business has changed from paper and branch banks to digitized and networked banking services. The internal accounting and management systems of banks have already changed. It is now fundamentally changing the delivery systems banks use to interact with their customers (Magutu et al., 2009). All over the world, banks are aiming to find a technological 
PROBLEMS

OF MANAGEMENT

IN THE $21^{\text {st }}$ CENTURY

Volume 2, 2011

122

internet and other related technologies and applications are changing the banking industry. Banks with the ability to invest and integrate information technology are therefore bound to dominate the highly competitive global market. Investing in ICT is thus critical. Its potential and consequences on the banking industry future is enormous, especially with $m$-Banking. Mobile telephone communication providers inaugurated and support mobile financial services ranging from personal account monitoring to mobile banking and money transfers: $m$-Banking. Other products include payments of utility bills like electricity and water. The commercial banks have further embraced the Visa service feature in their debit and credit cards; enabling customers to carry out transactions over the internet. Magutu et al (2009) assert that Kenya has achieved significant success in the implementation of electronic banking; it is on the top of the emerging markets in this area and even outpaces the achievements of some developed countries.

The IT industry has grown exponentially in a push-pull fashion over recent years. On one hand, demand is being placed on businesses to operate and compete in the global marketplace, for vast opportunities created by the increase of Information systems in the business place. On the other hand, the continual advances in IS technologies, both in hardware and software, are often seen to be forcing businesses to modify the way they do business in order to accommodate the new technology to implement. The problem that many businesses face, after having made the decision to implement a new Information System, is subsequently deciding the optimum level of technology for them. Today's marketplace is intensely competitive and information delivery is so critical to successful business operations and management (Teo and Too, 2000). However, it is not just the information alone that is important, it is the effective and timely processing of information that enables a business to increase its value.

Venkatesh, (2000) identified that information is necessary for many different functions of an organization including "day-to-day operations, planning, controlling, organizing and decision-making". The use of computers in managing information has brought about the area of 'Information Systems' and it is stated by Venkatesh, (2000) that this is "concerned not only with the development of new information technologies but also with questions such as: how they can best be applied, how they should be managed, and what their wider implications are". The word 'system' is a commonly used term and can be associated with "almost every conceivable field of activity". Research has made it clear that assumptions are made about people's understanding of the term.

Technology in banks originally was meant to reduce costs and to enhance different functions, but the biggest dilemma, however, is to how to maintain a satisfactory number of face-to-face interactions with the customers (Smith, 1987). According to Leire et al., (2009) ICT includes financial software, e-banking, and the Internet and is considered one of the most common means of increasing revenue, achieving economies of scale, and reducing unit costs. ICT also enables larger volumes of up-to-date information to be readily obtained (Vasarhelyi and Greenstein, 2003) and it facilitates efficient management of treasury positions (Shon and Swatman, 1998). It also improves financial forecasts and planning; optimizes financing and investment of treasury deficits and surpluses; identifies financial risks that can then be monitored or hedged rapidly and systematically; and allows simulations to compare contracting of different hedging products (Loderer and Pichler, 2000).

According to Koh et al., (2007) the five key practical achievements of technological developments in any financial institution are the removal of repetitive, time consuming tasks, reduction in human error and extended access to banking related facilities. This is celebrated in the provision of customer information that it would be much more expensive to provide on a person-to-person basis. The terms personal computer (PC) banking, Internet banking, virtual banking, online banking, home banking, remote electronic banking, and phone banking are used to describe the various types of electronic banking are often used interchangeably (Zeithaml, 2000). 
Leire et al., (2009) further examined the relationships within financial departments of firms with respect to their use of ICT in cash management, perceptions of the importance of cash management to unit performance, and perceptions of ICT's usefulness to this performance. They developed and tested an explanatory model of factors explaining the perceived importance of ICT to the performance of financial departments of organizations. Cash management entails: liquidity management, banking management, management of treasury deficit financing and investment of treasury surpluses, and management of financial risks. As a management tool, ICT is used in all operations involving financial decision making. Use of ICT within the financial department of a firm typically incorporates an information and communication process that draws on many technological tools (financial software, e-banking, and the Internet).

Continuous software improvements in the information technology have enabled banks to provide their services in a more direct manner to adjust their products better to the clienteles' needs. Although banking has always been an information business, until now information technology was mainly used to automate administrative processes. The shift from automating to informating-using information and its flow to inform managers provides opportunities to track a customer's behavior and respond at the right time. By making effective use of these opportunities, banks are able to transfer a great deal of transactions from branch offices to a call-centre (Yang and Fang, 2004). Accessibility has been extended through technological developments as well as the introduction of new service delivery methods that allow consumers to do business with service firms from the home and office.

According to Zhang and Prybutok, (2005) electronic banking technology is a set of instructions and procedure designed to respond to situations and process cases to achieve the results specified in the mandate of the agency. This is therefore an aspect of the design of process for transforming materials to finished products. It does not refer to machines and equipment only. Utilization of technology today, offers dramatic and enduring improvements in enhacing organizational performance (Port, 1993).

According to Dabholkar, (1994) internet banking allows customers to perform tasks at a time and in a place convenient to them. Direct contact with such technology also gives customers a feeling of greater control. Internet banking is predicted to transform and revolutionalize traditional banking industry (Leire et al, 2009). Banking services are easily digitalized and automated and, thus, from an operational perspective, lend themselves to the internet (Adrienne et al., 2003) the potential competitive advantage of the internet for banks lies in the areas of cost reduction and satisfaction of consumer needs.

Automated Teller Machines (ATMs) are also known as electronic cash machine: an electronic machine that enables customers to withdraw paper money or carry out other banking transactions on insertion of an encoded plastic card (msn.encarta). Automated teller machines (ATMs) are nothing new, but not all cardholders make full use of all the facilities that ATMs offer. Due to ignorance or technophobia, many clients still opt for more cumbersome and costly methods of banking (Stanley and Roach, 2000). Bank clients, who hate waiting in long queues at the bank, prefer ATM banking. It offers the customer the convenience of being able to do most of their banking from a machine often situated outside the bank, so that they have access to their bank account 24 hours a day.

\section{Problem of Research}

An interest in analyzing changes from ICT dates back to Galbraith's (1973) study of the role of information in organizations. In the initial stages, studies of ICT use in firms were descriptive with findings focused on improvements that technology brings to the various information and management systems of companies, including: external and internal logistics and mechanization processes (Davenport and Short, 1990; Mulligan and Gordon, 
PROBLEMS

OF MANAGEMENT

IN THE $21^{\text {st }}$ CENTURY

Volume 2, 2011

2002), marketing operations, human resource management (Rayport and Sviokla, 1995), and information and management processes (Vasarhelyi and Greenstein, 2003). Instead of viewing business as a collection of independent, specialized functions, the value chain approach views business as a series of activities that create value. The value chain recognizes IT as a critical component because IT provides necessary linkages among the disparate value chain activities that require coordination. The relationship between IT investment and productivity has been a source of debate.

In Kenya specifically, developments in IT has developed in leaps and bounds; from $e$ Banking to $m$-Banking with. Just before $m$-Banking, a number of commercial banks allowed their customers to monitor their accounts over the internet: $e$-Banking. Some of the key aspects associated with $e$-commerce on banks business process management are retail transfer $e$-payments (ATM transactions, card-based $e$-money and cash withdrawals); there is use of electronic ID; security of operations has been enhanced, internet has been enhanced, there has been improved management of retail $e$-payments (credit and debit cards); electronic signatures are now stored and can be shared, with a lot of mobile applications. There is an increased wholesaler's $e$-payment (large value transfer systems, automatic clearing and credit transfers). There is also electronic document management, electronic registration process for customers, $e$-procurement and certification for security of payment (www.cbk.co.ke). There is need for a research to delineate the extent to which various facets of ICT are used and perceived as useful to commercial banks in Kenya at departmental level.

The impact of ICT on productivity was originally researched at the economic, industrial, and national level (Goss, 2001; Stiroh, 2002). Scholars have also addressed the productivity question at the organizational level (Brynjolfsson and Hitt, 2000; Chan, 2000; Nájera, 2005). One of the local surveys by Gichuhi, (2009), on the value of ICT in the banking industry in Kenya did not address commercial banks and the narrow perspective of finance department.

Although a number of studies have been done, there is no evidence of the business value or usefulness of ICT at departmental level in commercial banks, particularly in Kenya. ICT helps organizations by providing information that is critical to making and evaluating decisions. ICT is used intensively in financial departments because it facilitates management of treasury, optimizes short-term decisions of financing and investment, and facilitates identification of financial risks. There is little to no supporting research of its value at this level, an issue which this study intends to address. Accordingly, it is important to assess and explain the perceived usefulness of ICT in cash management, which is the focal activity of the financial department of commercial banks in Kenya.

This paper therefore sought to delineate the business value of the rapid developments in information communications technology and innovations used by commercial banks in Kenya at their finance departments. The main objective of the paper was to investigate the business value of the rapid developments of information communication technologies in the financial departments of commercial banks in Kenya. The specific objectives were: to delineate the extent to which various facets of information communications technology (ICT) are used by the commercial banks in Kenya; and to investigate the economic benefits of the information communications technology and innovations used by commercial banks in Kenya at their finance departments.

\section{Research Focus}

According to Leire et al., (2009) the business value of ICT in the banking industry especially the finance department focuses on three indicators of commercial bank performance: cost savings, improvements in the quality of the information, and enhancements in the use of scenario simulations for decision making. 
In Leire et al., (2009) assessment of the performance of an organization's finance department, they used three indicators important to treasury managers: cost savings, improvements in information quality, and enhancements in the use of scenario simulations in decision making. This study uniquely contributed to the debate about ICT "pays offs" and the growing number of studies that report ICT impact across various measures and levels (Brynjolfsson and Hitt, 2000) in that it examines ICT's perceived impact on productivity at the departmental level - that of the finance department. Moreover, they provided and tested an explanatory model of this influence.

Information Communication Technology (ICT) has seen developments that have been specifically geared towards to customer satisfaction, growth of business for the bank and the employee all for the purpose of lessening the cost of doing business and raising profits. Presently, the banking sector in Kenya has grown to be more sophisticated and the focus has turned to the business process management and the quality of service offered to the customers (Magutu et al., 2009). The sector has essentially metamorphosed from manual paper work in the banking halls; long lines at the tellers' cabins; and large sums in cash out of the banks and back into the banks to Automated Teller Machines (ATM), plastic money, electronic transactions involving transfers of large sums of money from via Remote Banking (one of the most important modern banking services enabling the customer to make payments from any place in the world and at any time via a Personal Computer (PC), fixed or mobile phone while assured of security of the transaction over the internet (www.swedbank.lv). This has been referred to as e-Business or ecommerce by various researchers. The significance of e-commerce in economic development the world over cannot be gainsaid. ICT has greatly lessened the cost of doing business and spurred profits for investments. This in turn has led to increased Direct Foreign Investments (DFIs) especially in the developing economies, Kenya included.

Of late, the latest drive towards innovation has motivated the industry into looking towards IT and ecommerce as a vital tool for simplifying the complexity of the banking process (Magutu et al., 2009). Among the benefits of these developments is massive cost cutting measures that has seen shoring up of profits for the sector. In equal measure, the sector has witnessed untold fraud perpetuated by techno-savvy entrepreneurs that has led to losses to private individuals, investments and even government agencies. This is not only a problem in Kenya but the world over. However, this study will focus on these implications and others within the Kenyan market.

IT productivity has been measured at different levels, including that of nation, sector, and organization although some of this research reported no relationship between IT investment and performance (Strassmann, 1985), while others reported positive associations (Brynjolfsson and Hitt, 1996).

The banking industry is deriving business value from their technology and innovations. Substantial cost savings can arise because applications that use the internet and the internetbased technologies like intranets and extranets are typically less expensive to develop, operate and maintain than traditional systems (O'brien and Marakas, 2008). Although studies of 1980s and into the 1990s did not find significant productivity gains associated with IT investment, often presenting inconclusive results (Berndt and Malone, 1995; Oliner and Sichel, 2000). Jorgenson and Stiroh, (1995) suggested that IT contributed more to productivity growth than ordinary capital.

Further according to O'brien and Marakas, (2008) other primary sources of business value include attracting new customers with innovative marketing and services, and retaining present customers with improved customer service and support. And of course generating revenues through electronic commerce applications to summarize most banks are building ebusiness e-commerce websites to achieve six major business values; Generate new revenues from online sales, reduce transaction costs through online sales and customer support, attract 
PROBLEMS

OF MANAGEMENT

IN THE $21^{\text {st }}$ CENTURY

Volume 2, 2011

126

new customers through via web marketing and advertising and online sales, increase the loyalty of existing customers via improved web customer service an d support, develop new web based markets and distribution channels for existing services and develop new information-based services accessible on the web.

Computer based financial management systems support business managers and professionals in decision s concerning the financing of business and the allocation and control of financial resources within business. Major financial management system categories include cash management (forecast and mange cash position), investment management [manage shortterm and other securities), capital budgeting (evaluate risk and return of capital expenditures), financial forecasting, and financial planning (forecast financial performance and financing needs). For example, the capital budgeting process involves evaluating the profitability and financial impact of proposed capital expenditures. Long-term expenditure proposals for facilities and equipment $t$ can be analyzed using a variety of return on investment (ROI) evaluation techniques.

According to Leire et al., (2009) this application makes use of spreadsheet models that incorporate present value analysis of expected cash flows and profitability analysis of risk to determine the optimum mix of capital projects for a business.

Financial analysts also typically use electronic spreadsheets and other financial planning software to evaluate the presentt and projected financial performance of a business. They also help determine the financial needs of business and analyze alternative methods of financing. Financial analysts use financial forecasts concerning the economic situation, business operations, types of financing available, interest rate and stocks and bond prices to develop optimal financing plan for the business alternatives (O'brien and Marakas, 2008).

Electronic spreadsheet packages, DSS software, and web-based groupware can be used to build and manipulate financial models. Answers to what-if and goal-seeking questions can be explored as financial analysts and mangers evaluate their financing and investment $t$ alternatives (O’brien and Marakas, 2008 \& Leire et al., 2009).

Much of this study will therefore focus on O'brien and Marakas, (2008) studies and Leire et al., (2009) the business value of ICT in the banking industry based on three indicators of commercial bank performance: cost savings, improvements in the quality of the information, and enhancements in the use of scenario simulations for decision making.

According to Nájera (2005), several studies have been done on the impact of ICT application on organizational performance, which have drawn upon theoretical frameworks from economic theory to explain proposed relationships between ICT investment and various performance indicators, including: productivity, market value, and profitability. The major conclusion or worry is "why the contribution of ICT is so difficult to measure", that is despite significant technological advances and increasing organizational investment in these technologies, the problem of underutilized systems plagues businesses (Venkatesh, 2000).

Today, management's embrace of new technology is a crucial indicator of how successfully ICT will be diffused throughout an organization to improve business performance (Koh, Nam, Prybutok, and Lee, 2007). The Primary contributions of ICT to performance can be measured at the operational level within a firm (Barua et al., 1995). Though ICT is used extensively in financial departments, there is little to no supporting research of its value at this level, an issue which this study intends to address. 
Peterson OBARA MAGUTU, Nixon ONCHARA MUGANDA, Gladys MONCHARI ONDIMU. The Facets and Economic Benefits of the Information Communications Technology and Innovations Used By Commercial Banks in Kenya

\section{Methodology of Research}

\section{General Background of Research}

This study was conducted using a descriptive survey design. This type of design involves a study of a phenomenon at its present being. Mugenda and Mugenda, (1999) pointed out that a survey research design attempts to collect data from members of a population to describe an existing phenomenon by asking individuals about their opinions, attitudes, behaviours or values. This therefore makes this survey design appropriate for this study because the researcher intends to collect data and opinions to ascertain the business value of the rapid developments of information communication technologies in the financial departments of commercial banks in Kenya for their enhanced overall performance advantage.

\section{Sample of Research}

The study targeted all the commercial banks in Kenya. The population of the study comprised of forty-four commercial banks incorporated and, or licensed to operate in Kenya. The unit of analysis was all the finance departments' officers in the commercial banks operating in Kenya. From the forty-four financial departments of the mainstream banks in Kenya, at least three respondents (financial managers, financial administrators, ICT managers and treasury managers) were chosen. The respondents (persons responsible for treasury management) were chosen using simple random selection. A sample size of hundred respondents was to be used. Mugenda and Mugenda, (1999) pointed out that a sample size of 30-100 is representative enough to make valid scientific and business inferences and conclusions.

\section{Instrument and Procedures}

To guarantee the highest possible number of replies, research respondents were made aware of the study in advance by means of a letter indicating the purpose and importance of the research. The main instruments for data collection were questionnaires and document analysis. Questionnaires were used to obtain information from the commercial banks' treasury management. They were preferred in this study because those taking part in the study will be literate and quite able to answer items asked adequately. The questionnaire items of the instruments have some overlapping elements. This type of questionnaire requires yes/no answers, filling in blank spaces, explaining, ticking the applicable answers. The questionnaires were made up of three parts: part I had the personal information and the Bank information. This section collected information related to demographic data such as age, gender, qualifications, experiences etc. Bank information include the Customer base, Bank type and size. Part II had the information communication technologies used in the financial departments of commercial banks in Kenya, to answer the first research objective. Part III had questions on the business value of the rapid developments of information communication technologies in the financial departments of commercial banks in Kenya to answer the second objective.

\section{Data Analysis}

Business value in any organization is the cumulative increase in one or more of the following: direct benefits (increased revenue or reduced costs); indirect benefits (customer relationships; flexibility increases, increased agility in response to market changes; and risk reduction) (Gliedman, 2000). The conceptual framework below depicts the business value at 
PROBLEMS

OF MANAGEMENT

IN THE $21^{\text {st }}$ CENTURY

Volume 2, 2011

128

the finance department (Dependent Variable) as generating new revenues from online sales, reduce transaction costs through online sales and customer support, attract new customers through via web marketing and advertising and online sales, increase the loyalty of existing customers via improved web customer service and support, develop new web based markets and distribution channels for existing services and develop new information-based services accessible on the web.

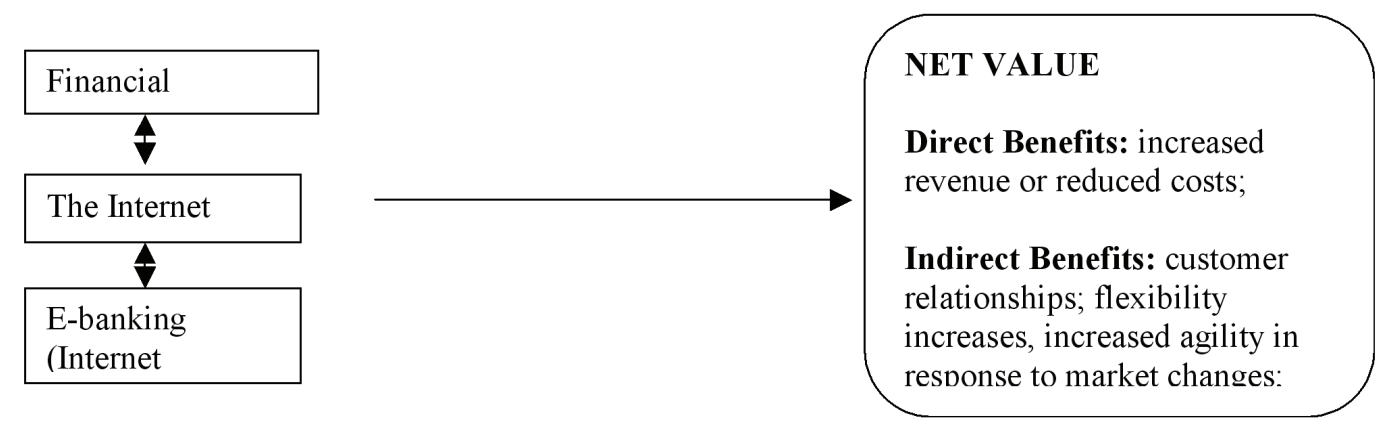

Figure 1: Conceptual Framework.

That the independent variables revolve around the formative constructs of indicators of financial software, the Internet and e-banking (internet banking). Thus overall value flows are dependent on these three constructs, which are by no means exhaustive but are considered as representative in this study. These relationships are captured in the conceptual framework above. The net business value is charged against: short-term banking forecasts, at least monthly; the establishment of an optimum cash level; optimization of liquidity; monitoring and optimization of the purchase-payment circuit; monitoring and optimization of the salescash circuit; monitoring of banking positions at the value date; day-to-day control of banking positions; maximization of returns on treasury surpluses; minimization of costs of short-term borrowing; coverage of exchange-rate risk and coverage of interest-rate risk.

The process of data analysis involved several stages. Completed questionnaires were edited for completeness and consistency. The data was then be coded and checked for any errors and omissions (Kothari, 1990). Frequency tables, percentages and means were used to present the findings. Responses in the questionnaires were tabulated, coded and processed by use of a computer Statistical Package for Social Science (SPSS) - version 12.0 programme to analyze the data. The response on open-ended questions were reported by descriptive narrative. The results of the study were compared with literature review to establish the business value of the rapid developments of information communication technologies in the financial departments of commercial banks in Kenya to enhance their performance.

\section{Results of Research}

Functions of Finance Departments of Commercial Banks

The finance departments in commercial banks have specific key functions that are supposed to perform. These activities may require the use of ICT, while others may not. Before assessing the ICT used in finance departments of commercial banks, there was need to check the specific key functions that are performed by finance departments of commercial banks. The respondents were asked to extent to which their banks have emphasized a number of activities that constitute the functions of finance departments of commercial banks using a five-likert scale where 5 = Very high extent; $4=$ High Extent; $3=$ No Effect; $2=$ Low Extent $\& 1=$ Very Low Extent. The descriptive results are as in table 1 below. 
Peterson OBARA MAGUTU, Nixon ONCHARA MUGANDA, Gladys MONCHARI ONDIMU. The Facets and Economic Benefits of the Information Communications Technology and Innovations Used By Commercial Banks in Kenya

From the research data in table 1 below, the three key functions (Mean $\geq 5=$ Very high extent, with a significant standard deviation) that are performed by finance departments of commercial banks are to perform or give short-term banking forecasts, at least monthly, secondly, to exercise day-to-day control of banking positions and lastly to cover the interestrate risk. The above three activities are the only ones that the study will focus on when checking on the applicability of ICT used in finance departments of commercial banks and the resultant the economic benefits of the information communications technology and innovations used by commercial banks in Kenya at their finance departments in performing the three key functions which are now absolute.

\section{Table 1. The Functions of Finance Departments of Commercial Banks}

\begin{tabular}{|l|c|c|c|}
\hline \multirow{2}{*}{ Functions of Finance Departments of Commercial Banks } & \multicolumn{2}{|c|}{ Descriptive Statistics } & \multirow{2}{*}{ Rank } \\
\cline { 2 - 3 } & Mean & Std. Deviation & \\
\hline Short-term banking forecasts, at least monthly & 5.0000 & 0.00000 & 1 \\
\hline Day-to-day control of banking positions & 5.0000 & 0.00000 & 2 \\
\hline Coverage of interest-rate risk & 5.0000 & 0.00000 & 3 \\
\hline Maximization of returns on treasury surpluses & 4.7294 & 0.44690 & 4 \\
\hline The establishment of an optimum cash level & 4.6706 & 0.47279 & 5 \\
\hline Coverage of exchange-rate risk & 4.6706 & 0.47279 & 6 \\
\hline Minimization of costs of short-term borrowing & 4.4000 & 0.49281 & 7 \\
\hline Monitoring and optimization of the sales-cash circuit & 4.3294 & 0.47279 & 8 \\
\hline Monitoring of banking positions at the value date & 4.2706 & 0.44690 & 9 \\
\hline Optimization of liquidity & 4.0000 & 0.00000 & 10 \\
\hline Monitoring and optimization of the purchase-payment circuit & 4.0000 & 0.00000 & 11 \\
\hline
\end{tabular}

Source: Research Data (2010)

The other functions ranked 4-11 (Mean $\geq 4=$ High Extent, with a significant standard deviation) that are performed by finance departments of commercial banks from the research data in table 1 above, are to maximization of returns on treasury surpluses, the establishment of an optimum cash level, coverage of exchange-rate risk, minimization of costs of shortterm borrowing, monitoring and optimization of the sales-cash circuit, monitoring of banking positions at the value date, optimization of liquidity, and monitoring and optimization of the purchase-payment circuit. Most of these functions are policy issues given by the central bank of Kenya, which are not within the control of commercial banks. This makes it hard for commercial banks to apply any ICT on management the dimensions of maximization of returns on treasury surpluses, the establishment of an optimum cash level, coverage of exchange-rate risk, minimization of costs of short-term borrowing, monitoring and optimization of the salescash circuit. But the function of monitoring of banking positions at the value date is an ignored function which commercial banks can automated and they should be seen to be doing it. This factor is expected to be among the three key functions, as it affected by short-term banking forecasts, at least monthly, day-to-day control of banking positions and the interest-rate risk. It can be taken as a moderating function in the subsequent analysis. These other functions ranking 4-11 will not be considered in the following discussions in 4.4 and 4.5.

Given that there are fewer than two cases, at least one of the variables has zero variance (ranking 1-3, $10 \& 11$ ), there is only one variable in the analysis, and correlation coefficients could not be computed for all pairs of variables. Therefore, no further statistics will be computed on functions of finance departments of commercial banks. 
PROBLEMS

OF MANAGEMENT

IN THE $21^{\text {st }}$ CENTURY

Volume 2, 2011

130

\section{Facets of ICT Used In Finance Departments of Commercial Banks}

ICT is used to automate processes and to augment the skills of the organization's staff. The first objective of the study was to delineate the extent to which various facets of information communications technology (ICT) are used by the commercial banks in Kenya. This was measured at three levels:

In the first level, the respondents were asked to give their opinion on how they see their finance department of their banks, and the results are as follows in table 4.2.

\section{Table 2. Opinion on the Finance Departments of Commercial Banks}

\begin{tabular}{|l|c|c|}
\hline \multirow{2}{*}{ Opinion } & \multicolumn{2}{|c|}{ Percentages } \\
\cline { 2 - 3 } & Frequency & Percent \\
\hline As a service centre which have an only objective, collections and payments & 57 & 67.1 \\
\hline $\begin{array}{l}\text { As a centre that with its activity offer to the firm profits because the management is } \\
\text { efficient }\end{array}$ & 28 & 32.9 \\
\hline Total & & 85 \\
\hline Source: Research Data (2010) & \multicolumn{2}{|c|}{100.0} \\
\hline
\end{tabular}

From the research data in Table 2 above, in the opinion of the respondents, the majority $(67.1 \%)$ view the finance department as a service centre whose only objective is collections and payments. This is actually in line with the two among the three functions established above as perform or give short-term banking forecasts and day-to-day control of banking positions. The issues of profits which received $34 \%$ is more strategic than a functional issue at departmental level.

In the second level, the respondents were asked to give extent to which the commercial banks used a number of technological tools in cash management in their finance department using a five - likert scale where $5=$ Usually; $4=$ Several times; $3=$ Many times; $2=$ Sometimes $\& 1=$ Never and the results are as follows in table 3 .

Table 3. The Technological Tools in Cash Management

\begin{tabular}{|l|c|c|c|}
\hline \multirow{2}{*}{ Technological Tools In Cash Management } & \multicolumn{2}{|c|}{ Descriptive Statistics } & \multirow{2}{*}{ Rank } \\
\cline { 2 - 4 } & Mean & Std. Deviation & 1 \\
\hline Financial Software & 4.7294 & 0.44690 & 2 \\
\hline E-banking (Internet Banking) & 4.4000 & 0.49281 & 3 \\
\hline The Internet & 3.8706 & 0.81340 & 3 \\
\hline
\end{tabular}

Source: Research Data (2010)

From the research data in table 3 above, the two commonly used technological tools (Mean $\geq 4.4$ = usually, with a significant standard deviation) in cash management in the finance department are the financial software and e-banking. This is in line with studies done by Leire et al., (2009), Vasarhelyi and Greenstein, (2003) and Shon and Swatman, (1998) which had noted that ICT in the banking industry includes financial software and e-banking as the most common means of increasing revenue, achieving economies of scale, and reducing unit costs.

In the third level, the respondents were asked to give the level of ICT use in cash management in its finance department in performing a number of activities using a five - likert scale where $5=$ Usually; $4=$ Several times; $3=$ Many times; $2=$ Sometimes $\& 1=$ Never and the results are as follows in table 4. 
Peterson OBARA MAGUTU, Nixon ONCHARA MUGANDA, Gladys MONCHARI ONDIMU. The Facets and Economic Benefits of the Information Communications Technology and Innovations Used By Commercial Banks in Kenya

From the research data in table 4, the above two ICT tools (the financial software and ebanking) have been fully applied (Mean $\geq 4.5=$ usually, with a significant standard deviation) in the management of cash peaks, in the management of account balances at value dates, and in the management of interest \& exchange rate risks. This concurs with Shon and Swatman's, (1998) observation that technological tools enables commercial banks to handle larger volumes of up-to-date to facilitate efficient management of treasury positions and improve financial forecasts and planning.

Table 4. The Level of ICT Use in Finance Department

\begin{tabular}{|l|c|c|c|}
\hline \multirow{2}{*}{ The Level of ICT Use In Finance Department } & \multicolumn{2}{|c|}{ Descriptive Statistics } & \multirow{2}{*}{ Rank } \\
\cline { 2 - 3 } & Mean & Std. Deviation & 1 \\
\hline Management of cash peaks & 4.6706 & 0.47279 & 2 \\
\hline Management of interest \& exchange rate risks & 4.6706 & 0.47279 & 3 \\
\hline Management of account balances at value dates & 4.6000 & 0.49281 & 4 \\
\hline Management of payments made and received & 4.3294 & 0.47279 & 5 \\
\hline Monitoring of liquidity of banking operations & 4.2706 & 0.44690 & 6 \\
\hline Short-term cash forecasts & 4.0706 & 0.85619 & 7 \\
\hline Management of cash deficit funding & 3.9412 & 0.77694 & 8 \\
\hline Negotiation with other banks & 3.6706 & 0.47279 & \\
\hline
\end{tabular}

Source: Research Data (2010)

The tools are equally useful in the management of payments made and received, monitoring of liquidity of banking operations, short-term cash forecasts, management of cash deficit funding, and negotiation with other banks. Issues related with negotiation are dominated with people and not ICT. Deficits, liquidity and payments are equally policy issues which are handled by the central bank.

\section{Discussion}

The business value of ICT in the finance department of the banking industry is multifaced, but it was not clear on which ones accrue to commercial banks. The second objective of the paper was to investigate the economic benefits of the information communications technology and innovations used by commercial banks in Kenya at their finance departments.

The respondents were asked to score the business value of the use of ICT in their bank's financial departments on a five - likert scale where 5 = Very high extent; $4=$ High Extent; $3=$ No Effect; 2 = Low Extent \& $1=$ Very Low Extent. The descriptive and factor analysis output are as in table 5 and 6 below. 
PROBLEMS OF MANAGEMENT IN THE $21^{\text {st }}$ CENTURY Volume 2, 2011

132

\section{Table 5. Business Value of ICT Used In Finance Departments}

\begin{tabular}{|c|c|c|c|}
\hline \multirow[b]{2}{*}{ Business Value of ICT Used In Finance Departments } & \multicolumn{2}{|c|}{ Descriptive Statistics } & \multirow[b]{2}{*}{ Rank } \\
\hline & Mean & $\begin{array}{l}\text { Std. Devia- } \\
\text { tion }\end{array}$ & \\
\hline $\begin{array}{l}\text { ICT use has ensured proper management of account balances at value } \\
\text { dates }\end{array}$ & 4.7765 & 1.00447 & 1 \\
\hline ICT has helped in the monitoring and optimization of the sales-cash circuit & 4.6471 & 0.48072 & 2 \\
\hline ICT has led to system responsiveness to changing user needs. & 4.5882 & 0.58338 & 3 \\
\hline ICT has made more and more up-to-date information & 4.5529 & 0.83817 & 4 \\
\hline ICT has helped in the coverage of exchange-rate risk & 4.4941 & 0.82554 & 5 \\
\hline ICT has helped in the establishment of an optimum cash level & 4.4235 & 0.82197 & 6 \\
\hline $\begin{array}{l}\text { ICT has led to prompt processing to requests for change to the existing } \\
\text { system. }\end{array}$ & 4.4118 & 0.49507 & 7 \\
\hline ICT has helped in the maximization of returns on treasury surpluses & 4.3059 & 1.03537 & 8 \\
\hline ICT has enabled ease of access for users to computing facilities. & 4.2824 & 0.88118 & 9 \\
\hline Users' willingness to find time to learn the system. & 4.2706 & 0.44690 & 10 \\
\hline ICT use has ensured proper management of payments made and received & 4.2235 & 0.77730 & 11 \\
\hline ICT use has ensured proper negotiation with other banks & 4.2235 & 0.77730 & 12 \\
\hline ICT use has ensured proper management of cash peaks & 4.2118 & 1.01294 & 13 \\
\hline ICT has enabled fast respond time from finance department & 4.2000 & 0.98561 & 14 \\
\hline ICT has increased the ability to improve personal productivity. & 4.2000 & 0.92324 & 15 \\
\hline ICT has enabled provision for disaster recovery. & 4.1882 & 0.82367 & 16 \\
\hline $\begin{array}{l}\text { ICT has helped in the monitoring and optimization of the purchase-payment } \\
\text { circuit }\end{array}$ & 4.1882 & 0.90625 & 17 \\
\hline ICT has helped in the day-to-day control of banking positions & 4.1529 & 1.35845 & 18 \\
\hline User confident in system. & 4.1412 & 0.62016 & 19 \\
\hline ICT has helped in the coverage of interest-rate risk & 4.1176 & 1.37505 & 20 \\
\hline ICT has led to savings in costs & 4.0000 & 0.88641 & 21 \\
\hline ICT has helped in the minimization of costs of short-term borrowing & 4.0000 & 1.06904 & 22 \\
\hline $\begin{array}{l}\text { ICT has led to flexibility to produce professional reports (e.g. graphics and } \\
\text { desktop publishing). }\end{array}$ & 3.9882 & 0.91929 & 23 \\
\hline ICT has enabled short-term banking forecasts, at least monthly & 3.9882 & 0.91929 & 24 \\
\hline ICT use has led to sound monitoring of liquidity of banking operations & 3.9412 & 1.00419 & 25 \\
\hline ICT use has led optimization of liquidity & 3.8824 & 0.99297 & 26 \\
\hline ICT has increased the quality of the report delivered to the user. & 3.8000 & 0.66904 & 27 \\
\hline ICT has helped in the monitoring of banking positions at the value date & 3.8000 & 0.94868 & 28 \\
\hline Flexibility of the system with regards to both data reports. & 3.7176 & 0.45282 & 29 \\
\hline ICT use has ensured proper management of cash deficit funding & 3.7176 & 0.45282 & 30 \\
\hline
\end{tabular}

Source: Research Data (2010)

From the research data in table 5, the five key economic benefits of the information communications technology and innovations (Mean $\geq 4.5=$ Very high extent, with a significant standard deviation) that have accrued to the commercial banks in Kenya at their finance departments include (Rank 1-5): ICT use has ensured proper management of account balances at value dates. Financial management software and e-banking has indeed enabled the ATM machines and over the counter transactions to be kept up to date. Secondly, ICT has helped in the monitoring and optimization of the sales-cash circuit. The circulation of money within the bank is equally well managed with financial software, given that banks are like cash sellers. Thirdly, ICT has led to system responsiveness to changing user needs. The financial software and e-business tools give flexibility to the financial department when dealing with the everchanging customer needs. Fourthly, ICT has made more and more up-to-date information since most banking transactions are real-time processing system. Lastly, ICT has helped in the coverage of exchange-rate risk

The other seventeen key economic benefits of the information communications technology and innovations (Mean $\geq 4.0=$ High Extent, with a significant standard deviation) 
Peterson OBARA MAGUTU, Nixon ONCHARA MUGANDA, Gladys MONCHARI ONDIMU. The Facets and Economic Benefits of the Information Communications Technology and Innovations Used By Commercial Banks in Kenya

that have accrued to the commercial banks in Kenya at their finance departments to high extent include (Rank 6-22): ICT has helped in the establishment of an optimum cash level; ICT has led to prompt processing to requests for change to the existing system; ICT has helped in the maximization of returns on treasury surpluses; ICT has enabled ease of access for users to computing facilities; Users' willingness to find time to learn the system; ICT use has ensured proper management of payments made and received; ICT use has ensured proper negotiation with other banks; ICT use has ensured proper management of cash peaks; ICT has enabled fast respond time from finance department; ICT has increased the ability of the system to improve personal productivity; ICT has enabled provision for disaster recovery; ICT has helped in the monitoring and optimization of the purchase-payment circuit; ICT has helped in the day-today control of banking positions; User confident in system; ICT has helped in the coverage of interest-rate risk; ICT has led to savings in costs; and ICT has helped in the minimization of costs of short-term borrowing.

The remaining eight economic benefits that have not been realized by the financial department of commercial banks include: flexibility to produce professional reports (e.g. graphics and desktop publishing); short-term banking forecasts, at least monthly; sound monitoring of liquidity of banking operations; optimization of liquidity; the quality of the report delivered to the user; the monitoring of banking positions at the value date; flexibility of the system with regards to both data reports; and proper management of cash deficit funding

The factors were far too many and factor analysis was performed on the economic benefits of the information communications technology and innovations used by commercial banks in Kenya at the finance departments, in order to reduce the factors into some meaningful number.

The results of the factor analysis using principal component analysis as an extraction method led to eight (8) components extraction in table 6 a. From the output in table 6 a, where total variance is explained, only eight components/factors were extracted and this explains $88.395 \%$ (on the extraction sums of squared loadings) of the economic benefits of the information communications technology and innovations used by commercial banks in Kenya at the finance departments.

Table 6a. Total Variance Explained: Business Value of ICT Used In Finance Departments

\begin{tabular}{|c|c|c|c|c|c|c|}
\hline \multirow{2}{*}{$\begin{array}{c}\text { Compo- } \\
\text { nent }\end{array}$} & \multicolumn{4}{|c|}{ Initial Eigenvalues } & \multicolumn{3}{c|}{ Extraction Sums of Squared Loadings } \\
\cline { 2 - 7 } & Total & \% of Variance & Cumulative \% & Total & $\%$ of Variance & Cumulative \% \\
\hline 1 & 8.491 & 28.303 & 28.303 & 8.491 & 28.303 & 28.303 \\
\hline 2 & 4.277 & 14.256 & 42.559 & 4.277 & 14.256 & 42.559 \\
\hline 3 & 3.918 & 13.061 & 55.620 & 3.918 & 13.061 & 55.620 \\
\hline 4 & 3.054 & 10.179 & 65.798 & 3.054 & 10.179 & 65.798 \\
\hline 5 & 2.283 & 7.609 & 73.408 & 2.283 & 7.609 & 73.408 \\
\hline 6 & 1.858 & 6.194 & 79.602 & 1.858 & 6.194 & 79.602 \\
\hline 7 & 1.442 & 4.808 & 84.410 & 1.442 & 4.808 & 84.410 \\
\hline 8 & 1.196 & 3.985 & 88.395 & 1.196 & 3.985 & 88.395 \\
\hline 9 & 0.897 & 2.990 & 91.386 & & & \\
\hline 10 & 0.823 & 2.745 & 94.131 & & & \\
\hline 11 & 0.630 & 2.098 & 96.229 & & & \\
\hline 12 & 0.444 & 1.480 & 97.710 & & & \\
\hline 13 & 0.252 & 0.838 & 98.548 & & & \\
\hline
\end{tabular}

\author{
PROBLEMS \\ OF MANAGEMENT \\ IN THE $21^{\text {st }}$ CENTURY \\ 133
}


PROBLEMS OF MANAGEMENT IN THE $21^{\text {st }}$ CENTURY Volume 2, 2011

134

\begin{tabular}{|l|c|c|c|l|l|l|}
\hline 14 & 0.185 & 0.615 & 99.163 & & & \\
\hline 15 & 0.122 & 0.406 & 99.569 & & & \\
\hline 16 & 0.083 & 0.276 & 99.845 & & & \\
\hline 17 & 0.034 & 0.115 & 99.960 & & & \\
\hline 18 & 0.012 & 0.040 & 100.000 & & & \\
\hline 19 & $7.794 \mathrm{E}-16$ & $2.598 \mathrm{E}-15$ & 100.000 & & & \\
\hline 20 & $4.726 \mathrm{E}-16$ & $1.575 \mathrm{E}-15$ & 100.000 & & & \\
\hline 21 & $3.269 \mathrm{E}-16$ & $1.090 \mathrm{E}-15$ & 100.000 & & & \\
\hline 22 & $2.799 \mathrm{E}-16$ & $9.331 \mathrm{E}-16$ & 100.000 & & & \\
\hline 23 & $2.003 \mathrm{E}-16$ & $6.675 \mathrm{E}-16$ & 100.000 & & & \\
\hline 24 & $7.415 \mathrm{E}-17$ & $2.472 \mathrm{E}-16$ & 100.000 & & & \\
\hline 25 & $-4.981 \mathrm{E}-17$ & $-1.660 \mathrm{E}-16$ & 100.000 & & & \\
\hline 26 & $-1.643 \mathrm{E}-16$ & $-5.475 \mathrm{E}-16$ & 100.000 & & & \\
\hline 27 & $-2.929 \mathrm{E}-16$ & $-9.763 \mathrm{E}-16$ & 100.000 & & & \\
\hline 28 & $-3.767 \mathrm{E}-16$ & $-1.256 \mathrm{E}-15$ & 100.000 & & & \\
\hline 29 & $-4.875 \mathrm{E}-16$ & $-1.625 \mathrm{E}-15$ & 100.000 & & & \\
\hline 30 & $-1.054 \mathrm{E}-15$ & $-3.514 \mathrm{E}-15$ & 100.000 & & & \\
\hline
\end{tabular}

Extraction Method: Principal Component Analysis.

Source: Research Data

Table 6b. Component Matrix (a): Business Value of ICT Used In Finance Departments.

\begin{tabular}{|l|c|c|c|c|c|c|c|c|}
\hline $\begin{array}{l}\text { Business Value of ICT Used In } \\
\text { Finance Departments }\end{array}$ & \multicolumn{7}{|c|}{ Component } \\
\hline & 1 & 2 & 3 & 4 & 5 & 6 & 7 & 8 \\
\hline $\begin{array}{l}\text { ICT has enabled ease of access for } \\
\text { users to computing facilities. }\end{array}$ & $\mathbf{0 . 9 3 5}$ & -0.109 & -0.055 & -0.081 & -0.049 & 0.168 & 0.139 & 0.030 \\
\hline $\begin{array}{l}\text { ICT has led to prompt processing to } \\
\text { requests for change to the existing } \\
\text { system. }\end{array}$ & $\mathbf{0 . 8 5 0}$ & 0.044 & 0.249 & -0.100 & 0.138 & -0.060 & -0.238 & -0.002 \\
\hline $\begin{array}{l}\text { ICT has increased the ability of } \\
\text { the system to improve personal } \\
\text { rroductivity }\end{array}$ & $\mathbf{0 . 8 4 4}$ & -0.078 & -0.165 & -0.136 & 0.248 & 0.019 & -0.007 & -0.105 \\
\hline $\begin{array}{l}\text { ICT has led to flexibility to produce } \\
\text { professional reports (e.g. graphics } \\
\text { and desktop publishing). }\end{array}$ & $\mathbf{0 . 7 7 2}$ & 0.273 & 0.217 & 0.394 & 0.107 & 0.076 & 0.252 & -0.167 \\
\hline $\begin{array}{l}\text { ICT has enabled short-term banking } \\
\text { forecasts, at least monthly }\end{array}$ & 0.698 & -0.243 & 0.555 & 0.124 & -0.274 & 0.111 & 0.159 & 0.077 \\
\hline $\begin{array}{l}\text { ICT has helped in the monitoring of } \\
\text { banking positions at the value date }\end{array}$ & $\mathbf{0 . 6 9 0}$ & 0.024 & -0.161 & 0.448 & -0.115 & 0.463 & -0.231 & -0.014 \\
\hline $\begin{array}{l}\text { ICT has made more and more up-to- } \\
\text { date information }\end{array}$ & $\mathbf{0 . 6 7 3}$ & 0.157 & -0.257 & -0.064 & -0.360 & -0.273 & -0.056 & .250 \\
\hline $\begin{array}{l}\text { ICT use has ensured proper man- } \\
\text { agement of cash deficit funding }\end{array}$ & $\mathbf{0 . 6 5 1}$ & 0.032 & -0.080 & 0.335 & 0.288 & -0.224 & .149 & -0.193 \\
\hline $\begin{array}{l}\text { ICT use has ensured proper man- } \\
\text { agement of cash peaks }\end{array}$ & $\mathbf{0 . 6 2 9}$ & 0.508 & 0.034 & 0.182 & 0.091 & 0.253 & -0.414 & 0.090 \\
\hline $\begin{array}{l}\text { Users' willingness to find time to } \\
\text { learn the system. }\end{array}$ & $\mathbf{0 . 6 2 5}$ & 0.278 & 0.623 & -0.137 & 0.134 & -0.192 & 0.142 & .042 \\
\hline $\begin{array}{l}\text { CT has led to system responsive- } \\
\text { ness to changing user needs. }\end{array}$ & $\mathbf{0 . 6 1 9}$ & -0.522 & 0.145 & -0.356 & 0.269 & 0.060 & -0.024 & -0.035 \\
\hline $\begin{array}{l}\text { ICThas enabled provision for disas- } \\
\text { ter recovery. }\end{array}$ & $\mathbf{0 . 5 9 1}$ & -0.170 & -0.253 & 0.385 & 0.269 & 0.054 & 0.299 & 0.318 \\
\hline
\end{tabular}


Peterson OBARA MAGUTU, Nixon ONCHARA MUGANDA, Gladys MONCHARI ONDIMU. The Facets and Economic Benefits of the Information Communications Technology and Innovations Used By Commercial Banks in Kenya

\begin{tabular}{|c|c|c|c|c|c|c|c|c|}
\hline $\begin{array}{l}\text { TCT has helped in the monitoring and } \\
\text { optimization of the purchase-pay- } \\
\text { ment circuit }\end{array}$ & 0.575 & 0.338 & -0.358 & -0.089 & -0.203 & 0.113 & 0.142 & -0.395 \\
\hline $\begin{array}{l}\text { ICT has helped in the minimization of } \\
\text { costs of short-term borrowing }\end{array}$ & 0.562 & 0.490 & -0.024 & 0.024 & 0.117 & 0.192 & -0.536 & 0.047 \\
\hline User confident in system. & 0.527 & 0.248 & 0.513 & -0.329 & 0.222 & -0.223 & 0.169 & 0.060 \\
\hline $\begin{array}{l}\text { TCT use has ensured proper man- } \\
\text { agement of payments made and } \\
\text { received }\end{array}$ & -0.126 & 0.749 & -0.402 & 0.448 & -0.154 & -0.070 & 0.082 & -0.061 \\
\hline $\begin{array}{l}\text { ICT use has ensured proper negotia- } \\
\text { tion with other banks }\end{array}$ & -0.126 & 0.749 & -0.402 & 0.448 & -0.154 & -0.070 & 0.082 & -0.061 \\
\hline $\begin{array}{l}\text { ICT use has led optimization of } \\
\text { liquidity }\end{array}$ & -0.100 & 0.599 & 0.298 & -0.447 & 0.226 & 0.098 & -0.326 & -0.100 \\
\hline $\begin{array}{l}\text { ICT has helped in the coverage of } \\
\text { exchange-rate risk }\end{array}$ & -0.251 & 0.583 & 0.524 & 0.196 & -0.041 & -0.337 & 0.190 & -0.029 \\
\hline $\begin{array}{l}\text { TCT has helped in the day-to-day } \\
\text { control of banking positions }\end{array}$ & 0.074 & 0.537 & -0.318 & -0.375 & -0.051 & 0.395 & 0.472 & -0.175 \\
\hline $\begin{array}{l}\text { Flexibility of the system with regards } \\
\text { to both data reports. }\end{array}$ & -0.158 & 0.218 & 0.737 & 0.328 & 0.121 & 0.266 & 0.144 & -0.013 \\
\hline $\begin{array}{l}\text { TCT use has ensured proper } \\
\text { management of account balances at } \\
\text { value dates }\end{array}$ & -0.218 & 0.020 & 0.518 & 0.565 & 0.250 & 0.086 & -0.031 & 0.273 \\
\hline $\begin{array}{l}\text { ICT has helped in the maximization } \\
\text { of returns on treasury surpluses }\end{array}$ & 0.254 & -0.623 & 0.066 & 0.314 & -0.510 & 0.355 & 0.058 & 0.058 \\
\hline ICT has led to savings in costs & 0.349 & -0.310 & -0.644 & 0.082 & 0.281 & -0.005 & -0.036 & 0.187 \\
\hline $\begin{array}{l}\text { TCT has enabled fast respond time } \\
\text { from finance department }\end{array}$ & 0.204 & 0.266 & -0.431 & -0.256 & 0.443 & 0.008 & 0.355 & 0.480 \\
\hline $\begin{array}{l}\text { ICT has helped in the coverage of } \\
\text { interest-rate risk }\end{array}$ & -0.569 & 0.240 & -0.027 & 0.021 & 0.016 & 0.600 & 0.063 & 0.294 \\
\hline $\begin{array}{l}\text { ICT use has led to sound monitoring } \\
\text { of liquidity of banking operations }\end{array}$ & -0.562 & 0.280 & 0.202 & -0.337 & 0.278 & 0.420 & 0.059 & 0.181 \\
\hline $\begin{array}{l}\text { TCT has helped in the monitoring and } \\
\text { optimization of the sales-cash circuit }\end{array}$ & 0.336 & 0.047 & 0.167 & -0.641 & -0.406 & 0.372 & 0.158 & -0.103 \\
\hline $\begin{array}{l}\text { ICT has helped in the establishment } \\
\text { of an optimum cash level }\end{array}$ & 0.245 & 0.191 & 0.036 & 0.002 & -0.736 & -0.127 & 0.383 & 0.355 \\
\hline $\begin{array}{l}\text { ICT has increased the quality of the } \\
\text { report delivered to the user. }\end{array}$ & 0.284 & 0.383 & -0.294 & -0.430 & -0.338 & -0.281 & -0.130 & 0.397 \\
\hline
\end{tabular}

Extraction Method: Principal Component Analysis.

Source: Research Data

From the results in table $6 \mathrm{~b}$ of the factor analysis using principal component analysis as an extraction method, the above eight (8) components/factors can be explained as follows:

Component/Factor one: Financial Planning and Customer Satisfaction. Sounding financial planning and customer satisfaction is one of the business values of ICT used in finance departments. This can be explained by the ease of access for users to computing facilities; prompt processing to requests for change to the existing system; increased the ability of the system to improve personal productivity; flexibility to produce professional reports (e.g. graphics and desktop publishing); short-term banking forecasts, at least monthly; monitoring of banking positions at the value date; up-to-date information; proper management of cash deficit funding; proper management of cash peaks; responsiveness to changing user needs; provision for disaster recovery; monitoring and optimization of the purchase-payment circuit; minimization of costs of short-term borrowing; and user confident in system.

Component/Factor Two: Proper Management of Payments. Proper management of payments is the second business value of ICT used in finance departments. This can be explained by: proper management of payments made and received; proper negotiation with 
PROBLEMS

OF MANAGEMENT

IN THE $21^{\text {st }}$ CENTURY

Volume 2, 2011

136

other banks; optimization of liquidity; coverage of exchange-rate risk; and day-to-day control of banking positions.

Component/Factor Three: Proper Management of Account Balances. Proper management of account balances is the third business value of ICT used in finance departments. This can be explained by: flexibility of the system with regards to both data reports; and proper management of account balances at value dates

Component/Factor Fourth: Cost Savings. This is the fourth business value of ICT used in finance departments. This can be explained by: the maximization of returns on treasury surpluses; and savings in costs

Component/Factor six: Proper Monitoring and Optimization of Banking Operations. Proper monitoring and optimization of banking operations is the sixth business value of ICT used in finance departments. This can be explained by: sound monitoring of liquidity of banking operations; and the monitoring and optimization of the sales-cash circuit.

Component/Factor Fifth, Seven and Eight is explained by: fast respond time from finance department; the establishment of an optimum cash level; and increased the quality of the report delivered to the user. This is because ICT has enabled fast respond time from finance department; ICT has helped in the establishment of an optimum cash level; and ICT has increased the quality of the report delivered to the user.

The following eight economic benefits that have not been realized by the financial department need to be addressed within the commercial banks in Kenya: flexibility to produce professional reports (e.g. graphics and desktop publishing); short-term banking forecasts, at least monthly; sound monitoring of liquidity of banking operations; optimization of liquidity; the quality of the report delivered to the user; the monitoring of banking positions at the value date; flexibility of the system with regards to both data reports; and proper management of cash deficit funding. This is because the banking sector complexity and technological change should be the composite measure of perceived value of ICT in the banks' ICT planning process.

Areas of further research that were identified include a similar study to be carried out on other sectors of micro - financial sector, A study on the relationship between ICT planning intensity and financial performance should be done to determine how the relationship between ICT planning intensity and financial performance can be managed for optimization in the turbulent environment and to what extent can the non-financial benefits if any be quantified by the organizations.

\section{Conclusions}

Conclusions Based on the results from data analysis and findings of the research, the paper can safely conclude the following, based on the objective of the paer.

Firstly, the finance departments in commercial banks have specific key functions that are supposed to perform. These activities may require the use of ICT, while others may not. The three key functions that are performed by finance departments of commercial banks are to perform or give short-term banking forecasts, at least monthly; to exercise day-to-day control of banking positions and lastly to cover the interest-rate risk.

Secondly, ICT is used to automate processes and to augment the skills of the organization's staff. In view the finance department as a service centres whose only objective is collections and payments; the two commonly used technological tools in cash management in the finance department are the financial software and e-banking. The above two ICT tools have been fully applied in the management of cash peaks, in the management of account balances at value dates, and in the management of interest \& exchange rate risks.

Thirdly, the business value of ICT in the finance department of the banking industry is multi-faced, but it was not clear on which ones accrue to commercial banks. The five key 
Peterson OBARA MAGUTU, Nixon ONCHARA MUGANDA, Gladys MONCHARI ONDIMU. The Facets and Economic Benefits of the Information Communications Technology and Innovations Used By Commercial Banks in Kenya

economic benefits of the information communications technology and innovations that have accrued to the commercial banks in Kenya at their finance departments include: ICT use has ensured proper management of account balances at value dates; ICT has helped in the monitoring and optimization of the sales-cash circuit; ICT has led to system responsiveness to changing user needs; and ICT has helped in the coverage of exchange-rate risk.

Fourth, the factors were far too many and factor analysis was performed on the economic benefits of the information communications technology and innovations used by commercial banks in Kenya at the finance departments. Only eight (8) components/ factors were extracted in factor analysis on the economic benefits of the information communications technology and innovations used by commercial banks in Kenya at the finance departments.

\section{References}

Adrienne, et al., (2003). The relative importance of technology in enhancing customer relationships in banking - a Scottish perspective. International Journal of Bank Marketing, Vol. 14, No. 4, pp. 172-91.

Aral, S., Brynjolfsson, E., Van Alstyne, M. (2006). Information, technology and information worker productivity: task level evidence. 27th Annual Conference on Information Systems, Milwaukee, United States. Retrieved June 1, 2007, from Social Science Research Network [SSRN], http://ssrn.com/ abstract $=942310$.

Aral, S., Brynjolfsson, E., \& Wu, D.J. (2006). Which came fi rst, IT or productivity? The virtuous cycle of investment and use in enterprise systems. 27th Annual Conference on Information Systems. Milwaukee, United States. Retrieved June 1, 2010 from SSRN, http://ssrn.com/abstract $=942291$

Barua, A., Kriebel, H. C., \& Mukhopadhyay, T. (1995). Information technologies and business value: an analytic and empirical investigation. Information Systems Research, 6(1), 3-23.

Bender, D. H. (1986). Financial impact of information processing. Journal of Management Information Systems, 3(2), 22-32.

Berndt, E. R., \& Malone, T. W. (1995). Information technology and the productivity paradox: Getting the questions right. Economics of Innovation and New Technology, 3, 177-182.

Brynjolfsson, E. (1993). The productivity paradox of information technology: review and assessment. Communications of the ACM, 36(12), 66-77.

Brynjolfsson, E., \& Hitt, L. M. (1996). Paradox lost? Firm-level evidence on returns to information systems spending. Management Science, 42(4), 541-558.

Brynjolfsson, E., \& Hitt, L. M. (2000). Beyond computation: Information technology, organizational transformation and business performance. Journal of Economic Perspective, 14(4), 23-48.

Brynjolfsson, E., \& Yang, S. (1996). Information Technology and productivity: A review of the literature. Advances in Computers, 43, 179-214. In Leire San-Jose, Txomin Iturralde and Amaia Maseda, (2009), The Influence of Information Communications Technology (ICT) on Cash Management and Financial Department Performance: An Explanatory Model, ASAC.

Chan, Y. E. (2000). IT value: the great divide between qualitative and quantitative and individual and organizational measures. Journal of Management Information Systems, 16(4), 225-261.

Dabholkar, P. (1994), Technology based service delivery, Advances in Services Management, Vol. 3 pp.241-71. 
PROBLEMS

OF MANAGEMENT

IN THE $21^{\text {st }}$ CENTURY

Volume 2, 2011

138 Davenport, T. H., \& Short, J. E. (1990). The new industrial engineering: Information technology and business process redesign. Sloan Management Review, 31(4), 11-23.

Dedrick, J., Gurbaxani, V., \& Kraemer, K. L. (2003). Information technology and economic performance: A critical review of the empirical evidence. ACM Computing Surveys, 35(1), 1-28.

Dehning, B., \& Richardson, V. J. (2002). Returns on investments in information technology: A research synthesis. Journal of Information Systems, 16(1), 7-30.

Galbraith, J. R. (1973). Designing complex organizations. Chicago: Addison-Wesley Publishing Company.

Gichuhi Naftali, (2009). A Survey of the Value of ICT in the Banking Industry in Kenya. University of Nairobi, Unpublished MBA Project.

Goss, E. (2001). The Internet's contribution to U.S. productivity growth. Business Economics, 36(4), $32-42$.

Hitt, L. M., \& Brynjolfsson, E. (1996). Productivity, business profi tability, and consumer surplus: three different measures of information technology value. MIS Quarterly, 20(2), 121-142.

Jorgenson, D. W., \& Stiroh, K. (1995). Computers and growth. Economics of innovation and new technology, 3, 295-316. In Leire San-Jose, Txomin Iturralde and Amaia Maseda, (2009), The Influence of Information Communications Technology (ICT) on Cash Management and Financial Department Performance: An Explanatory Model, ASAC.

Koh, C. E., Nam, K., Prybutok, V. R., \& Lee, S. (2007). A value chain perspective of internet practices, e-readiness and organizational performance: A comparison of US and South Korean firms. Industrial Management and Data Systems, 107(4), 519-536.

Leire San-Jose, Txomin Iturralde, \& Amaia Maseda, (2009). The Influence of Information Communications Technology (ICT) on Cash Management and Financial Department Performance: An Explanatory Model, ASAC. Canadian Journal of Administrative Sciences Published by John Wiley and Sons, Ltd. 150 26(2), 150-169 (2009).

Litan, R., and Rivlin, A. (2001). Projecting the economic impact of the Internet. American Economic Review, 91(2), 313-317.

Loderer, C., \& Pichler, K. (2000). Firms, do you know your currency risk exposure? Survey results. Journal of Empirical Finance, 7(3-4), 317-344.

Luftman, J. N. (ed) (1996). Competing in the information age: strategic Alignment in Practice. Oxford printing press March - April.

Mcfarlan, F. W., Mc Kenney, J. L. \& Pyburn, P. (1983). The Information Archipelago - Plotting a course. Harvard Business Review, January - February.

Morgan Stanley, \& Roach, S. S. (1987). America's technology dilemma: A profile of the information economy. Special Economic Study. Morgan Stanley. In Leire San-Jose, Txomin Iturralde and Amaia Maseda, (2009), The Influence of Information Communications Technology (ICT) on Cash Management and Financial Department Performance: An Explanatory Model, ASAC.

Mulligan, P., \& Gordon, S. R. (2002). The impact of information technology on customer and supplier relationships in the financial services. International Journal of Service Industry Management, 13(1), $29-46$. 
Peterson OBARA MAGUTU, Nixon ONCHARA MUGANDA, Gladys MONCHARI ONDIMU. The Facets and Economic Benefits of the Information Communications Technology and Innovations Used By Commercial Banks in Kenya

Nájera, J. J. (2005). El estudio del impacto de la tecnología de la información sobre los resultados 139 empresariales: Unarevisión de la literatura. Paper presented at the XV National Conference of ACEDE, Tenerife, Spain.

O'Brien, J. A., \& Marakas G. M (2008). Management Information Systems: Managing Information Technology in the E-Business Enterprise. Tata McGraw-Hill Publishing Company Ltd., New Delhi.

OECD (2004). Information and communications technologies-OECD Information technology outlook 2004. Retrieved June 1, 2007, from http://www.oecd.org/dataoecd/20/47/33951035.pdf

Oliner, S. D., \& Sichel, D. E. (2000). The resurgence of growth in the late 1990s: Is information technology the story? Journal of Economic Perspectives, 14(4), 3-22.

Porter, M. E. (1980). Competitive strategy: Techniques for analyzing Industries and Competition. The free press, New York.

Porter, M. E., \& Millar, V. E (1995). How information gives you a competitive advantage. Harvard Business Review, July - August 2006.

Porter, M., \& Millar, V. E. (1985). How information gives you competitive advantage. Harvard Business Review, 63(4), 149-160. In Leire San-Jose, Txomin Iturralde and Amaia Maseda, (2009), The Influence of Information Communications Technology (ICT) on Cash Management and Financial Department Performance: An Explanatory Model, ASAC.

Rayport, J. F., \& Sviokla, J. J. (1995). Exploiting the virtual value chain. Harvard Business Review, 73(6), 75-85. In Leire San-Jose, Txomin Iturralde and Amaia Maseda, (2009), The Influence of Information Communications Technology (ICT) on Cash Management and Financial Department Performance: An Explanatory Model, ASAC.

Shon, T. H., \& Swatman, P. M. C. (1998). Identifying effectiveness criteria for Internet payment systems. Internet Research Electronic Networking Applications and Policy, 8(3), 202-218.

Smith, C. P. (1987). Retail Banking Technology. International Business Communications, London.

Solow, R. M. (1987). We'd better watch out. New York Times Book Review, July 12, 36.

Stiroh, K. (2002). Information technology and the U.S. productivity revival: A review of the evidence; the closer one looks, the more persuasive it is. Business Economics, Jan 2002. Retrieved June 1, 2007, from http://www.ny.frb.org/research/economists/stiroh/ks_rev2.pdf.

Strassmann, P. A. (1985). Information payoff: The transformation of work in the electronic age. Free Press, New York.

Teo, T. S. H., \& Too, B. L. (2000). Information systems orientation and business use of the internet: An empirical study. International Journal of Electronic Commerce, 4(4), 105-130.

Vasarhelyi, M., \& Greenstein, M. (2003). Underlying principles of the electronization of business: a research agenda. International Journal of Accounting Information Systems, 4(1), 1-25.

Venkatesh, V. (2000). Determinants of perceived ease of use: integrating control, intrinsic motivation, and emotion into the technology acceptance model. Information System Research, 11(4), 342-365. 
PROBLEMS

OF MANAGEMENT

IN THE $21^{\text {st }}$ CENTURY

Volume 2, 2011

140 Yang, Z. and Fang, X. (2004), Online service quality dimensions and their relationships with satisfaction: a content analysis of customer reviews of securities brokerage services, International Journal of Service Industry Management, Vol. 15 No. 3, pp. 302-26.

Zeithaml, V. (2000). Service quality, profitability and the economic worth of customers: what we know and what we need to learn. Journal of the Academy of Marketing Science, Vol. 28 No. 1, pp. 67-85.

Zeithaml, V. (2002). Service-excellence in electronic channels. Managing Service Quality, Vol. 12 No. 3 , pp. 135-8.

Zhang, P. (2000). The effects of animation on information seeking performance on the world wide web: securing attention of interfering with primary tasks? Journal of the Association for Information Systems, Vol. 1, No. 1, pp. 1-28.

Zhang, X., \& Prybutok, V. R. (2005). A consumer perspective of e-service quality. IEEE Transactions on Engineering Management, Vol. 52, No. 4, pp. 461-77.

Advised by Dana Egerova, University of West Bohemia, Czech Republic
Accepted: November 10, 2011

\author{
Accepted: November 10, 2011
}

Received: September 21, 2011

\begin{tabular}{|ll|}
\hline Peterson Obara Magutu & $\begin{array}{l}\text { Lecturer, Department of Management Science, School of Busi- } \\
\text { ness, University of Nairobi, BOX } 22427-00100, \text { Nairobi, Kenya. } \\
\text { E-mail: magutumop@yahoo.com }\end{array}$ \\
\hline Nixon Onchara Muganda & $\begin{array}{l}\text { Lecturer, Department of Management Science, School of Busi- } \\
\text { ness, University of Nairobi, Nairobi, Kenya. } \\
\text { E-mail: nixon.muganda@gmail.com }\end{array}$ \\
\hline Gladys Monchari Ondimu & $\begin{array}{l}\text { Part - Time Lecturer, Jomo Kenyatta University of Agriculture and } \\
\text { Technology, Nairobi, Kenya. } \\
\text { E-mail: gladysondimu@yahoo.com }\end{array}$ \\
\hline
\end{tabular}

